\title{
A ADEQUACC̃̃O E OTIMIZAÇÃO DO USO DA SALA DE CONVIVÊNCIA DA FCA/UNICAMP COMO ESPAÇO DE COMPARTILHAMENTO E DESENVOLVIMENTO DE PESSOAL
}

\section{Introdução:}

DOI: $10.20396 /$ sinteses.v0i7.10286

O projeto foi contemplado através do 4ํㅡ릴 do "Programa para Estímulo de Projetos Estratégicos" lançado pela Diretoria da FCA para apoiar financeiramente a execução de projetos que atendam aos objetivos estratégicos da Faculdade. A proposta da otimização da Sala de Convivência, objetiva não apenas a adequação física do ambiente, mas a construção de um espaço de compartilhamento, interação e troca de saberes. Para tanto, além de ações que operem na climatização, iluminação e conforto do local, são realizados bimestralmente encontros para exposição e discussão de temas de interesse dos servidores, cooperando com o seu desenvolvimento pessoal e profissional.

\section{Metodologia:}

As ações realizadas foram definidas em três eixos: o Gerenciamento do Projeto, a Adequação do Espaço Físico e a Realização dos Encontros Bimestrais. Os temas abordados nos encontros foram definidos pelos proponentes do projeto após pesquisa de interesse realizada com os servidores docentes, técnicos e administrativos da Faculdade. Ao final do projeto, será realizada avaliação do resultado, e proposição de novos projetos.

\section{Resultados:}

Se por um lado as tensões cumulativas resultam na fadiga e na queda da produtividade e criatividade (LIMONGI-FRANÇA, 2008), por outro a criação de um ambiente de descompressão favorece a abertura e a clarificação de problemas, principalmente através da comunicação. Para Vergara (2013), a comunicação interpessoal, ao provocar boas indagações, auxilia na resolução de problemas e na obtenção de pontos de vista diferenciados, o que além de resultar em soluções criativas, cooperam com o reequilíbrio homeostático fragilizado pela tensão. Segundo Lipp (2004), uma das principais formas de ajudar no processo de desestresse é a redução e/ou anulação de agentes externos que pressionam o indivíduo causando a tensão e desequilíbrio homeostático. Neste sentido, a mudança na estrutura física da Sala de Convivência e a realização dos encontros bimestrais, faz com que esse ambiente não se limite apenas à um espaço para realização de refeições, mas conquiste também a identidade de um lugar de relaxamento, compartilhamento e aprendizado de modo que "a aprendizagem informal proporciona um aprendizado incremental do que deve ser aprendido e sabido" (PANTOJA et al, 2010, p. 60).

\section{Considerações finais:}

A adequação do ambiente físico e o incentivo ao debate e ao compartilhamento de ideias através dos encontros proporciona maior integração da comunidade interna da Faculdade, contribuindo para construção de soluções compartilhadas e criativas, redução do estresse, favorecimento da interdisciplinaridade e da comunicação tanto interpessoal quanto intrapessoal. Ao final do projeto serão avaliados os resultados e a proposição de novos projetos específicos a partir dos temas debatidos nos encontros.
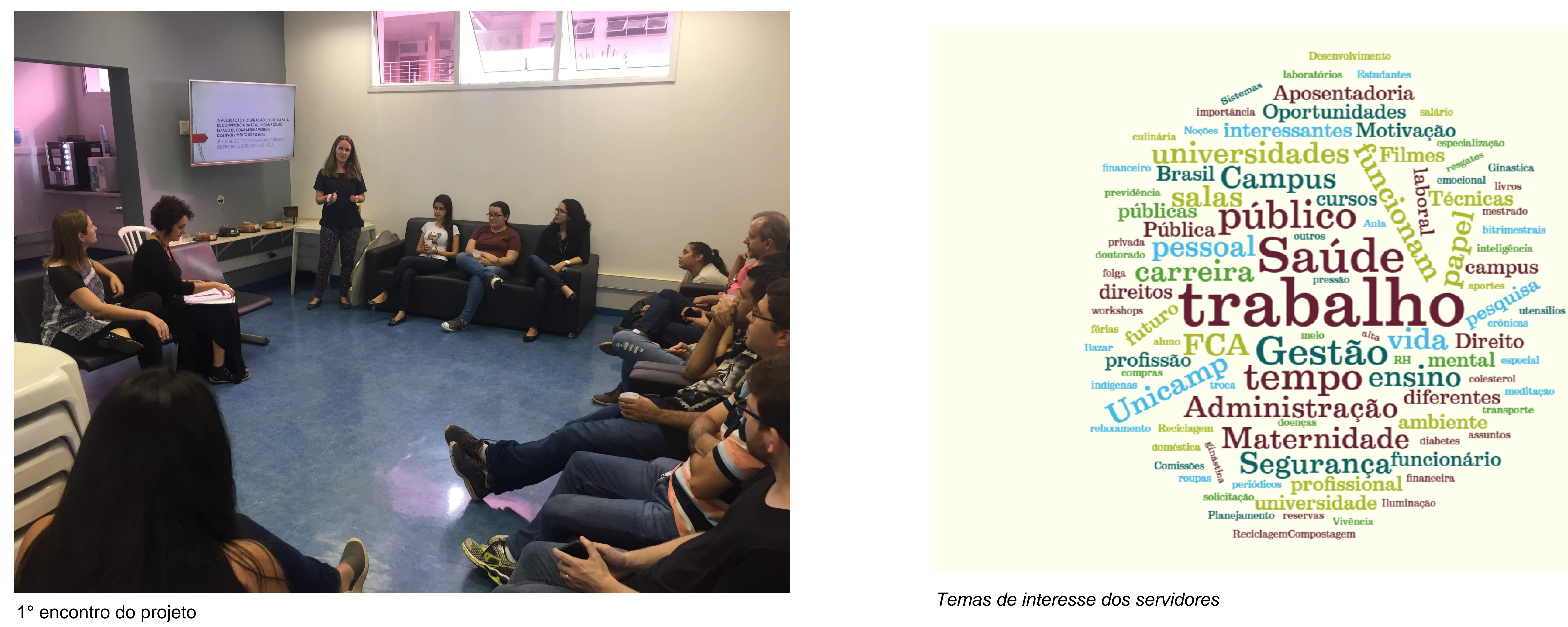

Temas de interesse dos servidores

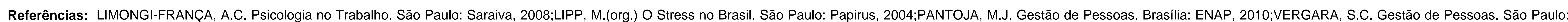
Atlas, 2013.

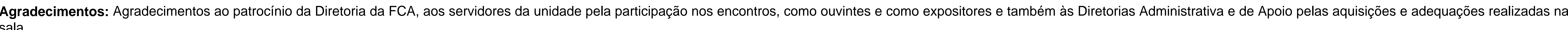

Sínteses: Rev. Eletrôn. SIMTEC, n. 7, e019201, set. 2019 - ISSN 2525-5398 